"This is a post-print version of an article published in Regional Environmental Change. The final published version is available online at: https://doi.org/10.1007/s10113-017-1230-5".

\title{
Pruning waste management and climate change in Sierra Mágina's olive groves (Andalusia, Spain).
}

Petra Benyei ${ }^{a^{*}}$, Marianne Cohen ${ }^{b}$, Etienne Gresillon ${ }^{c}$, Stéphane Angles ${ }^{\text {c }}$, Eduardo Araque-Jiménez ${ }^{\mathrm{d}}$, María AlonsoRoldán ${ }^{\mathrm{e}}$, Isidro Espadas-Tormo ${ }^{\mathrm{e}}$

a LASEG, ICTA, Universitat Autònoma de Barcelona, Spain petra.benyei@uab.cat

${ }^{\mathrm{b}} \mathrm{ENeC}$, UMR CNRS-Paris IV 8185, Université Paris-Sorbonne, France marianne.cohen@ paris-sorbonne.fr

${ }^{\mathrm{c}}$ LADYSS, UMR 7533, Université Paris Diderot -Paris 7, France etienne.gresillon@ wanadoo.fr, $\underline{\text { stephane.angles@ @ree.fr }}$

d HUM112, Departamento de Antropología, Geografía e Historia, Universidad de Jaén, Spain earaque@ujaen.es

e NGO PASOS, Spain isidro.espadas@gmail.com, marialonso@gmail.com

* Corresponding author: Institut de Ciència i Tecnologia Ambiental (ICTA), Universitat Autònoma de Barcelona, Despatx Z/145 Edifici ICTA-ICP, Carrer de les Columnes s/n 08193 Bellaterra (Spain). +34 935868649

\begin{abstract}
In the context of climate change, concern is raising about the negative effects of some pruning waste management practices. On the one hand, burning of pruning residue is seen as controversial regarding its contribution to greenhouse gas emissions. On the other hand, chipping the wood and using it as mulch is seen as highly risky regarding pest and disease control. Considering these issues, it is important to try to understand how and why these practices are adopted.
\end{abstract}

In this study we conducted in-depth interviews and survey questionnaires in the olive growing region of Sierra Mágina (Andalusia) in order to explore 1) which were the pruning waste management practices in place 2) which had been these practices in the past and 3) which were the factors influencing the choice of different practices.

Since 2010, there has been a shift in pruning waste management practices in this region, from stubble burning to chipping. This change seems to be led by older/retired farmers that have young and non-inherited groves. Moreover, this change is shown not to be necessarily a result of "greening" in agriculture but rather a result of intensification and mechanization. These results are discussed regarding the processes of innovation adoption in the region and the possible unforeseen externalities that derive from this change in pruning waste management practices.

\section{Key words}

Climate Change, changing practices, lexicometry, olive groves, pruning waste management, Sierra Mágina 


\section{Introduction}

Considering the major role that agricultural practices play in climate change mitigation and adaptation (Lal 2004; Smith et al. 2008) it is important to try to understand how and why these practices are adopted. However, the complexity of human decision making processes has favored extensive debate regarding this topic (Hayashi 2000; Edwards-Jones 2006). Some authors have focused on the role that social and political contexts play in shaping these practices (Ploeg 2009; Poppe et al. 2009). Some others (Rogers 2003; Geels and Schot 2007) have rather focused on the role of technological adoption dynamics. Furthermore, some authors suggest that these changes may respond to environmental challenges, including climate change (Smit and Skinner 2002). But overall, most research on this topic points out the importance of understanding the local stakeholders' perspective (Banville et al. 1998; Blackstock et al. 2010).

Moreover, long lasting adopted practices can change suddenly and in unexpected ways. This is so due to the multiple factors that influence stakeholders' decisions, but also due to the unforeseen effects of some of these practices. For example, burning of pruning residue has been widely used for a long time in agriculture as a method of pest and diseases prevention, particularly important in monocrop systems (Hardison 1976). Yet, in the context of climate change, concern is rising about its negative effects, especially regarding its contribution to increasing greenhouse gas emissions (Aguilera et al. 2015). However, current alternatives to this practice (chipping the wood and using it as mulch) also have their own drawbacks (Koski and Jacobi 2004; Cohen et al. 2017). All these elements contribute to shaping current pruning waste management practices.

Pruning waste management practices are those that are in place to dispose of the residual wood that is produced after pruning trees or other plants. These practices are very important in olive growing regions (such as Andalusia, Spain), due to the high amounts of residue generated and the labor intensity of the process (LaCal Herrera 2013). The main practices described in the literature have been stubble burning and chipping. However, these practices (as well as overall innovation diffusion challenges in olive grove farming) have mostly been studied following only econometric approaches (Parra-López and Calatrava-Requena 2005; Rodríguez-Entrena et al. 2013).

This paper contributes to this field of research by using a mixed methods approach to try to understand pruning waste management practices in the olive growing region of Sierra Mágina (Andalusia). Drawing form previous studies in the area that pointed out the region's vulnerability to climate change and some pruning waste management problems (Alonso-Roldán 2010; Cohen et al. 2014; Ronchail et al. 2014), this study explores 1) which are the current pruning waste management practices 2) which had been these practices in the past and 3) which are the factors influencing the choice of different practices. Moreover, we discuss the possible impacts of these practices in terms of mitigation and adaptation to climate change. These results contribute to the understanding of local agricultural dynamics and their deep roots, which is key in defining future climate change adaptation and mitigation proposals for this and other regions in the Mediterranean.

\section{Materials and Methods}

\section{Study area}


Sierra Mágina (Fig.1) is a small mountainous region (Comarca) in the Andalusian province of Jaén (Spain) that includes 15 municipalities (according to the Local Action Group report "Ficha Grupo de Acción Local-2012: ADR Sierra Mágina”; based on INE 2012).

Fig. 1 Map of Sierra Mágina region excluding La Guardia de Jaén, which by the time of writing this article was not any more considered as part of this region.

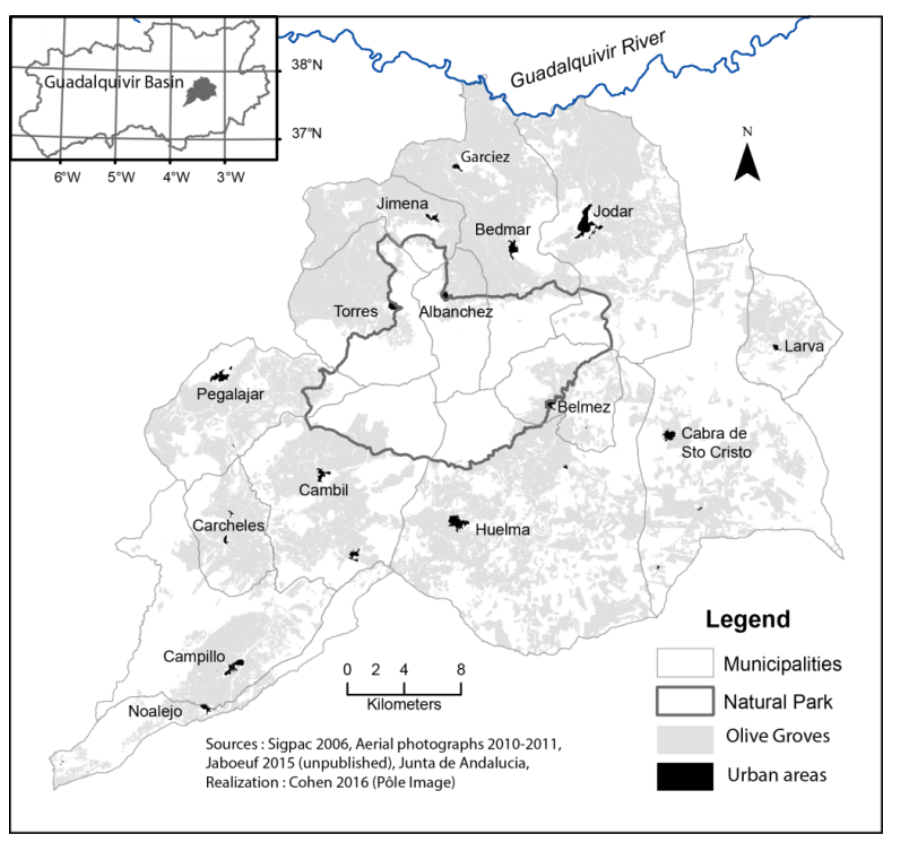

It has a surface area of around $1390 \mathrm{~km}^{2}$ and is, on average, the highest in altitude of the province, including mountain peaks reaching $2167 \mathrm{~m}$ above sea level (Sánchez Martínez and Gallego Simón 2010). Most of these peaks are part of the Sierra Mágina Nature Park that partially covers 9 of these municipalities. The area has a Mediterranean climate, with relatively cold winters and hot summers (moderated by the high altitude), and a low but variable rainfall (between 350 and 700mm p.a., see López Cordero and González Cano 2003). Landscape and land use have changed slowly but steadily since the second half of the nineteenth century, when most of the fallow land was set up for cultivation (López Cordero and González Cano 2003). But the most drastic changes came with the incorporation of Spain to the EU and the promotion of olive grove monoculture. This promotion contributed to the increase in olive grove cultivated area, which grew in these 15 municipalities from 63\% to 90\% of all agricultural land during the period 1986-2006 (Sánchez Martínez and Gallego Simón 2010). Furthermore, the 2009 Agrarian Census (which considers Mágina as a region with 10 municipalities, excluding by this means large areas of olive groves belonging to Carcheles and Pegalajar municipality) notes that $72 \%$ of all agricultural holdings in the region are dedicated to olive production.

This "sea of olive trees" is inhabited by 46,124 people (INE 2012), with a population density (32 inhabitants/km²) that is much lower than the national average (92 inh/ $\mathrm{km}^{2}$ according to INE 2012). Some elements that characterize this population according to the national statistics are: a declining population (reaching -72 people in terms of vegetative growth in 2009), growing internal emigration (with an internal migratory balance of -115 people in 2009), and a diminishing external immigration (that went from +195 to +94 external immigrants during the period 2007-2009). This situation (possibly triggered by the 2008 economic crisis) brings to mind past rural exoduses that took place during the 
1960 's, and that were only contained by effective price and production EU support to the olive sector (Araque-Jimenez 2008). The agricultural sector is the main economic sector in terms of employment and enterprises in the region; $63 \%$ of all employees and $62 \%$ of all enterprises (TGSS 2007). It is characterized by the predominance of olive groves which are heavily embedded in the region's landscape and culture (Angles 2014; Cohen et al. 2015). The olive groves of the hilly Sierra Mágina differ from the flat intensified olive groves found in most of Andalusia. Although irrigation is widely used and is one of the reasons for the permanence of most olive growers, there is still a considerable amount of rain-fed olive groves in the area (16,109 ha or $40 \%$ of olive grove surface area according to the 2009 Agrarian Census). At the same time, the complicated access to some areas has limited the mechanization of some of the holdings, making the traditional extensive olive grove system the most popular one (Vilar Hernández and Velasco Gámez 2010). Other differentiating characteristics, common to mountainous farming, are plot fragmentation and small farm size, low farmer professionalization (farming as secondary economic activity), farmer ageing and slow farm transmission (Alonso-Roldán 2010). In addition there are some commonalities with the rest of the sector, namely the importance of cooperatives and family businesses (Hernández Ortiz 2010) and the olive oil commercialization problems (bulk selling and low value adding according to García Brenes 2007 and Sanz Cañada et al. 2013).

Overall, these characteristics (especially the economic dependence on a rain dependent monocrop system) make the region vulnerable in the context of climate change. According to studies predicting climatic and yield variations in the area and exploring farmers' attitude towards climate change and climate mitigation strategies/proposals (Cohen et al. 2014; Ronchail et al. 2014), the predicted decrease in rainfall in the area could further affect olive grove productivity. These studies also found that there were environmental and management issues with the burning of pruning residues, since the carbon emissions were negatively influencing the environmental image of the PDO label, according to some farmers and cooperatives. Following these studies, our research focused on exploring those pruning waste management practices, trying to understand to what extent burning pruning residue was an issue, and trying to understand which practices were done in the past and which were the factors influencing the choice of practice.

\section{Qualitative methods}

The main qualitative method used in this study was in-depth interviewing. A series of key categories of stakeholders (farmers, pruning professionals, oil processors, formal experts and administration workers) were defined based on previous research done in the area (Alonso-Roldán 2010). Then, the categories were filled with sample units (following purposeful sampling; Patton 1990) from as many municipalities as possible (to try to cover the maximum variability). Each sample unit could correspond to more than one category (especially in the case of the farmers). In the end, 20 indepth interviews (average 40 minutes long) were conducted during March 2015, interviewing 8 farmers, 2 pruning professionals, 4 oil processors, 2 formal experts and 4 administration workers. Nevertheless, this sample did not cover all the categories as no willing interviewee was found for the political representative category (related to the fact that the 2015 electoral campaign was taking place in the villages), which leaves out important sources of information. Two different interview guidelines were developed; one for farmers and one for other stakeholders (see Electronic Supplementary Material). These scripts included questions characterizing the interviewees and questions on their perception of the evolution of farming practices (including questions on pruning waste management, questions about innovation issues and questions on policy influence in the region). 
The information gathered with this tool was analyzed using Grounded Theory (Corbin and Strauss 1990) and coding software tools such as Atlas.ti (Dowling 2008) and OpenCode (Umeå University 2013). By these means, the interviewees' discourse was reviewed and repeated ideas, concepts or elements were highlighted and assigned with codes. This process allowed us to grasp the core contradictions, ideas and categories regarding our research questions. To further deepen our understanding of each actor's discourse and the relationships between the interviewee's characteristics and their discourse line, lexicometry analysis was also used (Gavard-Perret et al. 2012). We used IRaMuTeQ software (Ratinaud and Déjean 2009), an R based interface that uses the ALCESTE algorithm to produce word count based statistics (Reinert 1983, 1986). This method compresses the information from our formatted pieces of discourse (compiled in large texts) through a process called "lemmatization" by which the different inflected forms of a word are grouped together. At the same time, the program differentiates between active and supplementary forms (Garnier and Guérin-Pace 2010). The active forms were the ones selected for our analysis. Each interviewee's discourse was labeled with explanatory variables, related to its social, professional and geographical profile. ALCESTE divided the text into Text Segments (TS) and calculated the frequency of word co-occurrences. Furthermore, ALCESTE identified clusters with a Descending Hierarchical classification Analysis (DHA). These TS clusters gather pieces of text containing similar vocabulary. The software develops and represents each cluster according to the most characteristic TS. It calculates the significance of words and profile variables associated with each cluster. Reinert (1983) considers each cluster as a "world", a relatively stable cognitive-perceptual framework, characterizing social representations. Through a differentiated selection of the participants according to their belonging to a group, the software makes it possible to establish the link between the profiles of the interviewees and the types of speech. In this paper we present the results obtained with the Reinert clustering method, applied to the answers regarding pruning practices by all the interviewees (Marpsat 2010).

\section{Quantitative methods}

The quantitative data gathering tool used was a farmer survey (see Electronic Supplementary Material). Although normally this is the basis of most previous research in the topic of innovation diffusion and farmer decision-making (Parra-Lopez et al. 2007; Rodríguez-Entrena and Arriaza 2013), our research followed a more participatory approach, asking stakeholders about their practices in the most open way possible. This is the main reason why the surveys were conducted afterwards and in a relatively small number (40 questionnaires). The sample was selected on the basis of spatial criteria. A number of key villages in the region were selected due to their specific characteristics and based on the existing bibliography. Five farmers from these villages were selected by convenience sampling (stopped randomly in the street at different times of the day). Although this sample cannot be considered probabilistic, since not all the farmers had the same chances of being selected, time constraints obliged the use of this sampling method. By gathering a dispersed, village-oriented sample, we were able to generate a map of questionnaires that would cover almost the whole region. Cartographic maps were shown during the survey so that the farmers could point out some of their properties. In the questionnaires, similar guidelines to the farmer's in-depth interview were used although the open questions from the interviews were transformed into quantitative questions, building Likert scales to measure information (Göb et al. 2007). With the responses to this survey, the first dataset was built. New variables were constructed following the analysis plan and continuous data was categorized (e.g. age, number of olive trees), following examples from the literature or using information from the interviewees on relative farm size in the region, for example. We ran a Multiple Correspondence Analysis (MCA) on this data using XLSTAT to analyze the questionnaire and its variables, which were split into two 
groups: those describing the pruning practices were in principal position (7), and those referring to the socio-professional profile and opinions about innovations and policy (39) in supplementary position (see Le Roux and Rouanet 2010 for further explanation of this method and Jaeger et al. 2011 for an example of its application in similar contexts). The unique case of a farmer using pruning residue for goat forage (39 individuals) was excluded from the sample. It is important to note that these analyses were exploratory $(n=40)$, and that we did not try to infer these results to the whole population.

\section{Results}

\section{Stakeholder in-depth interviews}

From the grounded theory based discourse analysis, we obtained information about current pruning waste management, its problems, the changes in management practices and the reasons behind practice choice. Regarding current waste management practices, all interviewees talked about stubble burning as a common way to eliminate the residues from olive tree pruning (although only 3/8 farmers stated burning residue as their only pruning waste management plan). However, many interviewees (14/20) talked about chipping as a growing waste management practice (commencement dated around 2010, later than suggestions by Calatrava and Franco 2011 for a neighbouring region). Some (11/20) talked about household use of the largest pieces of wood, a traditional practice mentioned as being re-introduced in recent years for economic reasons. A few interviewees (5/20) also talked about the use of the leafy branches for livestock fodder and bedding. Fewer interviewees knew about pharmaceutical uses for the leaves (1/20). Interviewees also agreed upon some points regarding pruning waste management problems, mainly when talking about stubble burning. One of the most recurrent issues was related to burning regulations and controls (mentioned by 6/20 interviewees). Another issue (4/20 interviewees) was the problem of pests related to the storage of olive tree wood ("Barrenillo" parasite, Phloeotribus scarabaeoides). Some interviewees (2/20) talked about environmental problems related to burning practices and one $(1 / 20)$ mentioned animal health issues related to forage uses of the waste (due to chemical products applied to the trees). Several interviewees (especially those with a higher education) considered the burning of pruning residue as a carbonneutral practice (although not expressed in these exact terms), with little environmental impact. Regarding changes in pruning waste management practices, the majority of interviewees (14/20) talked about the change to chipping as a general trend. The foreseen benefit of wood chips as organic matter when left in the soil was the main reason for this change (3/20 interviewees literally mentioned the concept of "organic matter"). However, many of them stated their continuity with previous waste management practices (6/8 farmers stated they still burn at least part of their waste). Some interviewees (2/20) also talked about the logistic problems of stubble burning as a reason for change (crop intensification doesn't leave space for burning in the field). On the contrary, costs related to the acquisition of machinery and costs related to plot fragmentation, orography and general logistic issues of chipping were the main reasons for the continuity of burning practices or (as 2/40 cases from our survey show) for returning to burning after a chipping experience. It is interesting to note that none of the interviewees (not even the technicians) talked about pest control issues related to chipping. When composting with wood chip, some experts (Koski and Jacobi 2004; Cohen et al. 2017) have found an increased probability of pest reproduction, which could be a major problem in a monoculture system like the one in place in Sierra Mágina.

The lexicometry analysis also partially supported these findings, although the small sample size (20 interviews) must be taken into account. The results from the word frequency statistics showed that three of the most frequently used forms 
when talking about pruning waste management referred to pruning practices: to burn ( $\mathrm{n}=75$ ), to chip ( $\mathrm{n}=71)$, to prune $(n=68)$, and its products: pruned branches $(n=59)$ and firewood $(n=36)$. Other frequent words were machine $(n=50)$ and problem $(n=50)$. The cluster analysis differentiated 3 groupings in a hierarchical way, each one using significantly these words (Table 1). Groups 1 and 2 represented 35.4 and $30.9 \%$ of the information respectively. They were opposed to group 3, which was the most significant, gathering $43.7 \%$ of the information. The category of interviewee $(*$ cat $)$ and the type of area where he lived was significantly related to the discourse groups (measured in word use). Experts and administration workers living in sloping land preferentially used a general discourse on the system including topics not directly linked to pruning practices, corresponding to their dominant social position. Some of them were also olive growers (nam_MR). Olive oil processors living in large cities were most focused on pruning products and processes. Farmers living in flat remote land significantly used words related to olive cultivation. Each group was also significantly linked to the name of some individuals (*nam) and the second group was also significantly related to the age group 40-60 years old. Words in a supplementary position also provided information: "nosotros" (us) was significantly linked to the group 3 ( $\mathrm{p}=0.0001)$, suggesting a collective way of thinking among farmers' group. "Burning" was used more by the farmers' group $\left(\mathrm{Chi}^{2}=9.45, \mathrm{p}=0.002\right)$ as it was "chipping" by the processors group $\left(\mathrm{Chi}^{2}=7.49, \mathrm{p}=0.006\right)$.

Table 1 Lexicometric cluster analysis of discourses on pruning practices and issues. For each group, the total word count, the percentage within the group, the $\mathrm{Chi}^{2}$ value.

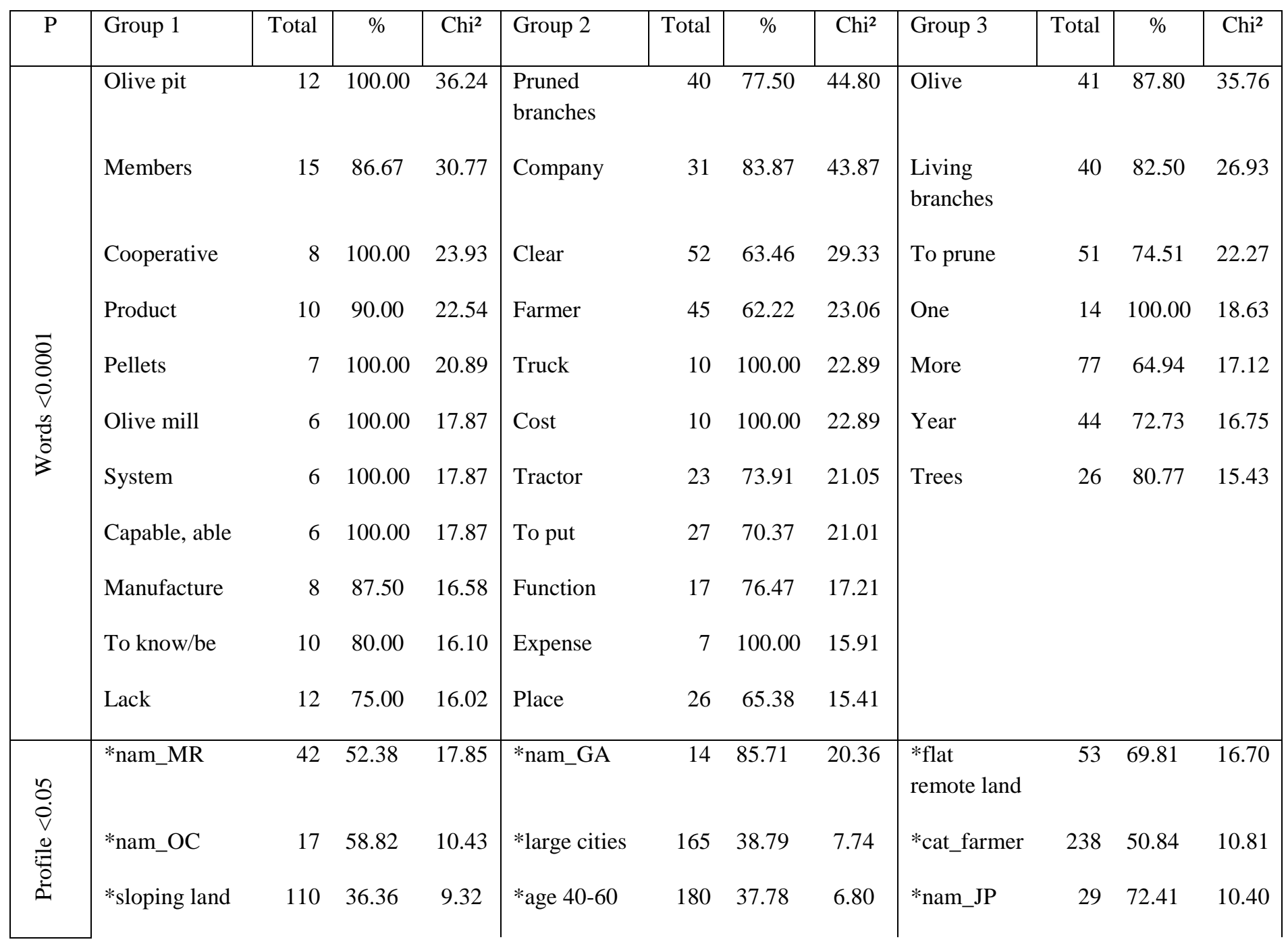




\begin{tabular}{|c|c|c|c|c|c|c|c|c|c|c|c|}
\hline $\begin{array}{l}{ }^{*} \text { cat }_{-} \\
\text {administration }\end{array}$ & 72 & 37.50 & 6.66 & *cat_process & 43 & 46.51 & 5.45 & *nam_MB & 24 & 66.67 & 5.44 \\
\hline *nam_OL & 8 & 62.50 & 5.92 & *nam_MN & 29 & 48.28 & 4.40 & *nam_JU & 26 & 65.38 & 5.28 \\
\hline *cat_expert & 28 & 42.86 & 4.81 & & & & & *nam_FR & 33 & 60.61 & 4.14 \\
\hline
\end{tabular}

\section{Farmer survey}

The results from the descriptive statistical analysis provided further information about past and current pruning waste management practices. Analysing current pruning waste management practices $(n=40), 30 \%$ of farmers were only chipping pruning residues while $37.5 \%$ were only burning them. However, $30 \%$ were partially chipping and $2.5 \%$ were using pruning waste in livestock farming, which in total made "exclusively burning" a less frequent practice than expected (although it was still the single most common practice). These percentages showed that there was still a large proportion of farmers who burned their pruning waste totally or partially. Analysing the change in pruning waste management practices (comparing current and previous practices) we found that $37.5 \%$ of the farmers continued exclusively burning, while $30 \%$ had totally changed to chipping. However, $27.5 \%$ had also partially changed to this practice and 5\% went back to burning after an unsuccessful chipping experiment, making the change to chipping a large trend, as the interviews had pointed out.

The MCA provided results on which variable categories were defining our respondents (Table 2). The first two axes described $67.26 \%$ of the adjusted inertia while the following axes described less than 5\% of the inertia. The first axis (Axis1) described 17 out of 39 farmers/respondents. This axis was significantly defined by the variable "Current pruning waste management", being positively associated with chipping and negatively associated with burning. The type and frequency of the pruning practice also had significant test values: Axis 1 (positively associated to chipping) was also positively associated to formation pruning (annual), intended to shape the trees (the case in young intensified groves), and negatively associated to rejuvenation pruning (biennial), intended to clear the branches to increase productivity (the case in older groves). Among the socio-economic variables (supplementary variables in Table 2), Axis 1 was significantly associated to land heritage and activity of the respondent variables. This axis was positively associated to retired farmers (normally over 65 years old) and non-inherited groves. The second axis (Axis2) described only 6 farmers and provided results that are less conclusive. This axis was also significantly defined by the variable "Current pruning waste management", being positively associated with burning and negatively associated with mixed management. Axis 2 (positively associated to burning) was also positively associated to formation pruning (meaning that it is associated to young groves as well). However, this axis was also positively associated to concentrated burning of the residues (a practice that is normally done in non-intensified groves due to the spacing necessary to mitigate the fire hazard). Yet, this axis was negatively associated to traditional agro-systems and positively associated with irrigation (typical of intensified groves). Moreover, this axis was positively correlated with farm workers (not land owners) and with being able to assess the quantity of pruning residue. Although being male is also positively associated to this axis, there was only one women in our sample. 
Table 2 Significant test-values of variable categories. Multiple Correspondence Analysis applied on 39 survey responses (supplementary variables are in grey characters; -: non-significant test-value)

\begin{tabular}{|c|c|c|c|}
\hline Variable & Category & Axis 1 & Axis 2 \\
\hline \multirow{3}{*}{ Current pruning waste management } & burning & $-3,628$ & 2,286 \\
\hline & mixed & - & $-2,947$ \\
\hline & chipping & $\mathbf{5 , 5 9 0}$ & - \\
\hline \multirow{4}{*}{$\begin{array}{l}\text { Type of pruning } \\
\text { (related to the age of the trees) }\end{array}$} & formation & 2,844 & 4,158 \\
\hline & mixed & - & - \\
\hline & no response & - & $-2,557$ \\
\hline & rejuvenation & $-2,466$ & - \\
\hline \multirow{3}{*}{ Pruning frequency } & annual & - & - \\
\hline & biennial & $-3,797$ & - \\
\hline & no response & 3,849 & - \\
\hline \multirow{2}{*}{ Quantity of residue } & assessed & $-2,191$ & 3,657 \\
\hline & no response & 2,191 & $-3,657$ \\
\hline \multirow{4}{*}{ Former pruning waste management } & burning & - & $-2,237$ \\
\hline & forage & - & $-2,351$ \\
\hline & no response & 2,208 & 2,402 \\
\hline & chipping & $-2,334$ & - \\
\hline \multirow{4}{*}{ Place of burning } & no burning & $\mathbf{5 , 5 9 0}$ & - \\
\hline & scattered & $-3,614$ & $-2,834$ \\
\hline & no response & - & - \\
\hline & concentrated & - & 2,943 \\
\hline \multirow{3}{*}{ Pruning service provider } & no response & - & 3,730 \\
\hline & no & - & $-2,623$ \\
\hline & yes & - & - \\
\hline \multirow{2}{*}{ Sex } & male & - & 1,973 \\
\hline & female & - & $-1,973$ \\
\hline \multirow{3}{*}{ Main activity } & farmer & - & - \\
\hline & other & - & - \\
\hline & retired & 2,425 & - \\
\hline \multirow{3}{*}{ Property of land } & mixed & - & - \\
\hline & property & - & - \\
\hline & worker & - & 2,712 \\
\hline \multirow{2}{*}{ Land heritage } & no & 2,275 & - \\
\hline & yes & $-2,275$ & - \\
\hline \multirow{3}{*}{ Type of agro-system } & intensive & - & - \\
\hline & mixed & - & 3,545 \\
\hline & traditional & - & $-4,169$ \\
\hline \multirow{3}{*}{ Irrigation } & no & - & - \\
\hline & yes & - & 2,073 \\
\hline & partial & $-2,151$ & $-1,994$ \\
\hline \multirow{2}{*}{ Technology acceptance } & low or null & - & - \\
\hline & strong & - & 2,178 \\
\hline
\end{tabular}




\begin{tabular}{|lll|}
\hline important & - & - \\
\hline average & - & - \\
\hline social & - & - \\
\hline
\end{tabular}

The results from the farmer survey contradict partially the results from the qualitative interviews. Although chipping is associated to younger intensified groves, older/retired farmers seem to be the ones taking up on this practice. Moreover, the burning practice was associated to contradictory variable categories, and also seems to be associated with young, modern groves. However, considering that this analysis is not able to explain 16 out of our 39 farmers and only describes $67.26 \%$ of the adjusted inertia, these results must be seen as partial and complementary to the stronger qualitative results.

\section{Discussion}

\section{Change to chipping}

The main finding of this research was that chipping was starting to substitute stubble burning as main pruning waste management practice in Sierra Mágina.'s olive groves. This change, that is in line with findings from other Andalusian regions (Calatrava and Franco 2011; Rodríguez-Entrena et al. 2013) could be unintentionally reducing the carbon footprint of Sierra Mágina olive groves and their contribution to climate change.

We found that the reasons for this shift were not necessarily based on environmental concerns or "green business" strategies. On the contrary, they were more in line with a fear of uncontrolled fires, and the consequential damage to olive trees, and increasingly stringent burning permit requirements. Also, in some cases, they were in line with larger plantation densities, related to intensification trends in olive-growing systems, although in some cases, pruning and residue management practices had nothing to do with the density of the groves. Paradoxically, we also found that the event that may have triggered this shift was a failed project led by the Bedmar oil cooperative aimed at collecting residue and transporting it to a biomass plant near Sierra Mágina. This project reflected the concern expressed by this stakeholder, interviewed in 2009, about the adverse public image of burning practices, while public awareness of climate change and greenhouse gas emissions was increasing. This cooperative is still failing in the economic valorisation of its oil product. Only 20\% is sold under the PDO label, the rest in bulk (García Brenes 2007; Sanz Cañada et al. 2013). Thus, its representatives thought that environmentally-friendly practices would give the product a better image and consequently a better price. Unfortunately, the company in charge of managing pruning waste for the cooperative members did not fulfil its commitments and failed to pick up the pruning residue left on the roadside by the farmers, who moreover, had to burn their residue in fear of pest propagation and fines. It is also important to note the convergence between the spreading chips on the ground and the eco-conditionality principle of the Common Agricultural Policy, aimed at soil protection (Calatrava Leyva et al. 2007; Sánchez Martínez and Gallego Simón 2010) and desertification prevention (Costa Pérez et al. 1999). This principle has been promoted vigorously in the region by technical staff, and erosion is perceived by local farmers as a major environmental problem (Cohen et al. 2014). This may well be incentivizing the shifting of practices. Finally, we found that the social relationships and solidarity between olivegrowers also helped to adopt these new practices, since the chipping machine was being loaned amongst neighbours (in line with the findings by Colombo and Perujo-Villanueva 2017). Thus, the reasons for change/permanence of practices differ greatly between stakeholders. Indeed, our results conclude that there is a diversity of discourses, rationale and 
practices related to pruning and residue management among local stakeholders (normally experts, administration workers and processors vs. farmers), and within the farmers' group itself. Some (mainly administration workers and experts) consider this practice to be more ecologically friendly, and thus support its implementation. On the other hand, most farmers mentioned the high costs of stubble burning (labour and fines/ regulations) as the reason for change, although many acknowledged the benefits of wood chips for soil maintenance.

The processes described by the interviewees and observed in the field contradict some of the previous research regarding technology adoption dynamics (Geels and Schot 2007; Rogers 2003). We found that innovations are sometimes incorporated at the local level to solve local problems, but without altering the entire technological regime, as is the case of chipping, were the innovation is partially adopted to solve stubble burning practical issues (mainly permits). These results also contrast with existing theories on transition in agriculture (Poppe et al. 2009; Van der Ploeg 2009). As seen in our case, environment-friendly practices such as chipping, based on the promotion of the ecological capital of the farming system (in line with Van der Ploeg's definition of repeasantization paths), may well be inserted in and driven by industrialization/artificialization processes. The shift to chipping (more environment-friendly than stubble burning) was mainly in line with a "productivist" approach (using Poppe et al. 2009 terminology) aimed at minimizing costs and maximizing productivity (by means of better soil quality obtained by leaving wood chips in the field). Moreover, the interviewed farmers aligned with organic farming practices were not interested in chipping, and were the drivers of livestock-related pruning waste management practices. Nevertheless, at a meeting of organic farmers held in Belmez de la Moraleda, in March 2015, pruning chip mulching was considered by speakers as part of the rationale of closing natural cycles: returning organic matter to the soil, minimizing transport costs and minimizing energy loss. These examples serve to make a point on how complex farmer decision making is and on the existence of a great diversity of factors that influence the actors' decisions, which lead to paths that cannot always be classified into separate boxes.

\section{Foreseeing externalities}

Besides chipping and mulching, other proposals have been designed as alternatives to stubble burning in the olive grove context. Researchers from Jaen University (the main regional university in the study area) have proposed gasification (producing biofuels from thermochemical conversion of olive wood biomass) as a solution for the region's pruning waste management problems ( $\mathrm{LaCal}$ Herrera 2013). Moreover, other researchers are investigating an innovative pathway to valorize pruning residue by obtaining biofuel, biochar (a soil fertilizer) and high value molecules via fungal pretreatment of pruning residue followed by pyrolysis (Cohen et al. 2017). These proposals have been designed as a way to mitigate climate change by offering alternatives to stubble burning, while at the same time solving economic and pruning waste management problems described by stakeholders. However, in the light of our findings on the emergence of chipping practices, we must look more closely at several issues. Firstly, we have to bear in mind that burning practices are useful for agriculture, as they can avoid the spread of plant disease (Hardison 1976). We must also remember that chipping and spreading wood chips on the soil that sustains the same crop may facilitate the propagation of bacterial and fungal diseases associated with that crop, especially in a long-term tree monoculture system such as olive growing in Sierra Mágina (Koski and Jacobi 2004, Cohen et al. 2017). This hazard was unknown by local stakeholders. This could also be the case with parasites like the "Barrenillo", which grows inside olive tree branches and is a well-known problem for farmers, or the olive fly disease. These diseases are already a major problem in olive-growing systems despite heavy control by aerial fumigation, with its high energy cost. Although the expected rise in temperatures (and longer warm 
periods) may not affect the biological cycle of some pests (such as the olive fruit fly), this is not the case for all (Ponti et al. 2014). Moreover, little is known about the future synchronization of the biological cycles of alternative host plants and fauna that contribute to the natural control of the olive fruit fly (Warlop 2006).

The crucial point is that there may be a contradiction between mitigation and adaptation to climate change in this case. Mitigation is increased by chipping pruning residue instead of burning it, and by spreading chips on the soil to avoid erosion and improve carbon content and storage in soils (Arrouays et al. 2002), which is currently very low (Ballais et al. 2013). However, the danger of uncontrolled pests and diseases is increased by these practices, increasing vulnerability and maladaptation to climate change. Moreover, endophytic fungi (genus Alternaria, containing many strains of opportunistic pathogens) has been found in pruning residue (Dicko et al. 2016), as observed in previous research (Chliyeh et al. 2014). In this case, the danger of fungal diseases could increase further if climate change triggers conditions that turn these opportunistic pathogens into active pathogens.

Although a shift to chipping would mitigate climate change in comparison with stubble burning, flaws have been detected in this new practice in terms of adaptation to climate change. By foreseeing the externalities of changing agricultural practices and by integrating the stakeholders in research, better and more sustainable technological solutions can be proposed.

\section{Conclusions}

This paper presented results that contribute to understand the rationale underlying the adoption of certain agricultural practices in Spanish mountain olive groves (Sierra Mágina, Andalusia). Specifically our aim was to explore what were the current and past pruning waste management practices and which were the factors influencing their adoption. We found that pruning waste management practices were changing in the region, and that stubble burning (previously the most common practice) was being substituted by chipping. This new practice seems to be led by retired farmers with newly bought groves (with young trees). This change was partly due to regulatory problems with burning and to crop intensification (lack of appropriate spacing for wild fire avoidance). We found that changes in pruning residue management were influenced by the personal situation of the farmers (e.g. land tenure status), and by the modernization of their farms (e.g. increased density of olive trees, irrigation and change from cereal cropping to olives). Analyzing their perception of these issues, we found that the distinctive discourse of each group is linked to the social position of the local stakeholders within the olive-growing social system. However, we could not find general rules or social determinism that could explain the choice of pruning practices.

Stakeholders and researchers detected advantages and issues in both types of practice. While stubble burning had been used for a long time as an effective means of pest control, it produces greenhouse gas emissions and thus contributes to climate change, although this practice was considered by some actors to be carbon-neutral. It also had a negative impact on consumer perception of the sustainability of olive groves, impacting on olive oil value-adding initiatives. Chipping, on the other hand, prevents the emissions of GHG, restores soil matter by leaving wood chips to be absorbed in the field, and can prevent water runoff. However, it is considered to be highly risky by some experts in terms of pest propagation (especially in the context of monoculture systems). 
In the light of these results, we can conclude that proposals aimed at climate change mitigation should consider not only parts of a system at a fixed moment in time, but the whole system and its very conceptualization in the long term. The contradiction of "ecological" practices (chipping) in agricultural monocrop and industrialized systems may have major effects for farmers and farming regions, especially considering the predicted dimensions of climate change. In addition, not foreseeing the externalities of these changes in agricultural practices can also lead to wrongly designed solutions. Innovative proposals can be developed to overcome some of the effects of climate change, but there is a need for systematic approaches and engagement of local stakeholders in the process of science building in order to better target and adapt proposals to real needs and to prevent negative externalities. Our multi-actor approach is a first step for implementing innovation in a local-friendly way, and including social and environmental issues.

\section{Acknowledgements}

This research was conducted in the context of the project "OLIZERO: Stratégies locales de valorisation énergétique de la biomasse. Vers des territoires oléicoles zéro carbone?" which was funded by the University Sorbonne Paris Cité under the Idex projects "Projet interdisciplinaire Lied 'Les énergies de demain"'. We would like to thank all the researchers who have collaborated on this project series for their corrections and suggestions, as well as to the anonymous reviewers and the editor of this journal for their comments and insights. We would also like to thank the locals of Sierra Mágina for their time and enthusiasm, especially to Miguel Yanes for facilitating researcher's housing and most of the interviews. Finally, we are also grateful to James Benyei for the proof reading of this manuscript.

\section{References}

Aguilera E, Guzmán G, Alonso A (2015) Greenhouse gas emissions from conventional and organic cropping systems in Spain. II. Fruit tree orchards. Agron Sustain Dev 35:725-737. doi: 10.1007/s13593-014-0265-y

Alonso-Roldán M (2010) The future of olive groves in sierra mágina regarding climate change. analysis of farmers’ perceptions. Master Thesis. Gent University

Angles S (2014) Les paysages de l'olivier, entre le mythe de la "méditerranéité" et la realité des enjeux territoriaux. Caiet Echinox 27:259-266.

Araque-Jimenez E (2008) Luces y sombras de la expansión olivarera en sierra mágina. Sumuntán 25:65-96.

Arrouays D, Balesdent J, Germon JC, et al (2002) Mitigation of the greenhouse effect. Increasing carbon stocks in French agricultural soils? INRA, Scientific Assessment unit for Expertise. Paris (France)

Ballais J-L, Cohen M, Bonté P, et al (2013) Hydric erosion in Sierra Magina olive groves (Andalusia, Spain) - Prospects for sustainable development. Zeitschrift für Geomorphol 57:1-23. doi: 10.1127/0372-8854/2012/0088

Banville C, Landry M, Martel J-M, Boulaire C (1998) A Stakeholder Approach to MCDA. Syst Res Behav Sci 15:15-32. doi: 10.1002/(SICI)1099-1743(199801/02)15:1<15::AID-SRES179>3.0.CO;2-B

Blackstock KL, Ingram J, Burton R, et al (2010) Understanding and influencing behaviour change by farmers to improve water quality. Sci Total Environ 408:5631-5638. doi: 10.1016/j.scitotenv.2009.04.029

Calatrava J, Franco JA (2011) Using pruning residues as mulch: Analysis of its adoption and process of diffusion in Southern Spain olive orchards. J Environ Manage 92:620-629. doi: 10.1016/j.jenvman.2010.09.023

Calatrava Leyva J, Franco Martínez JA, González Roa MC (2007) Analysis of the adoption of soil conservation practices in olive groves: the case of mountainous areas in Southern Spain. Spanish J Agric Res 5:249. doi:

10.5424/sjar/2007053-246 
Chliyeh M, Achbani EH, Rhimini Y, et al (2014) Pathogenicity of four fungal species on fruits and leaves of the olive tree (Olea Europaea L.). Internatioal J Pure Appl Sci 2:1-9.

Cohen M, Angles S, Marquez C, Araque-Jiménez E (2015) The Olive Grove: Productive Area or Landscape Heritage? A Comparison between Andalusia (Spain) and Southern Alps (France). In: Luginbuhl Y, Howard P, Terrasson D (eds) Landscape and sustainable development, the French perspective. Farnham, Ashgate, pp 121-132

Cohen M, Lepesant G, Lamari F, et al (2017) Biomolecules from olive pruning waste in Sierra Mágina - Engaging the energy transition by multi-actor and multidisciplinary analyses. J Environ Manage. doi: 10.1016/j.jenvman.2017.03.067

Cohen M, Ronchail J, Alonso-Roldán M, et al (2014) Adaptability of Mediterranean Agricultural Systems to Climate Change. The Example of the Sierra Mágina Olive-Growing Region (Andalusia, Spain). Part I: Past and Present. Weather Clim Soc 6:380-398. doi: 10.1175/WCAS-D-12-00043.1

Colombo S, Perujo-Villanueva M (2017) Analysis of the spatial relationship between small olive farms to increase their competitiveness through cooperation. Land use policy 63:226-235. doi: http://dx.doi.org/10.1016/j.landusepol.2017.01.032

Corbin J, Strauss A (1990) Grounded Theory Research: Procedures, Canons and Evaluative Criteria. Z Soziol. doi: 10.1515/zfsoz-1990-0602

Costa Pérez JC, Lozano Arribas R, Aragonés Espino J, et al (1999) Plan andaluz de control de la desertificación: sostenibilidad del olivar. In: VIII Simposio Cientifico-Tecnico, foro olivar y medioambiente.

Dicko M, Lamari FD, Lepesant G, et al (2016) Biomolecules from olive pruning waste in Sierra Mágina. In: CYPRUS 2016 4th International Conference on Sustainable Solid Waste Management.

Dowling M (2008) Atlas.ti (software). In: Given L (ed) The SAGE encyclopedia of qualitative research methods. SAGE Publications, Inc, Thousand Oaks, CA, pp 37-38

Edwards-Jones G (2006) Modelling farmer decision-making: concepts, progress and challenges. Anim Sci 82:783-790. doi: 10.1017/ASC2006112

García Brenes MD (2007) Transformaciones en la organización del trabajo en el cultivo del olivar. El caso de Andalucía. mundo Agrario 7 (14)

Garnier B, Guérin-Pace F (2010) Appliquer les méthodes de la statistique textuelle. CEPED, Paris

Gavard-Perret ML, Gotteland D, Haon C, Jolibert A (2012) Méthodologie de la recherche: réussir son mémoire ou sa thèse en sciences de gestion. Pearson Education France, Montreuil

Geels F, Schot J (2007) Typology of sociotechnical transition pathways. Res Policy 36:399-417. doi: 10.1016/j.respol.2007.01.003

Göb R, McCollin C, Ramalhoto MF (2007) Ordinal Methodology in the Analysis of Likert Scales. Qual Quant 41:601626. doi: 10.1007/s11135-007-9089-z

Hardison JR (1976) Fire and Flame for Plant Disease Control. Annu Rev Phytopathol 14:355-379. doi: doi:10.1146/annurev.py.14.090176.002035

Hayashi K (2000) Multicriteria analysis for agricultural resource management: A critical survey and future perspectives. Eur J Oper Res 122:486-500. doi: 10.1016/S0377-2217(99)00249-0

Hernández Ortiz M. (2010) La iniciativa emprendedora y la empresa familiar oleícola como motores de desarrollo en el ámbito rural. In: ADR Sierra Magina (ed) El olivar: Paisaje, patrimonio y desarrollo sostenible. Gráficas La Paz, Torredonjimeno, Jaén, pp 11-22

INE (2012) Instituto nacinal de estadística. http://www.ine.es/.

Jaeger SR, Bava CM, Worch T, et al (2011) The food choice kaleidoscope. A framework for structured description of product, place and person as sources of variation in food choices. Appetite 56:412-423. doi:

10.1016/j.appet.2011.01.012 
Koski RD, Jacobi WR (2004) Tree pathogen survival in wood chip mulch. J Arboric 30:165-171.

LaCal Herrera JA (2013) Viabilidad de la integración de una plata de gasificación de biomasa. Universiad de Jaén

Lal R (2004) Soil carbon sequestration impacts on global climate change and food security. Science (80- ) 304:16231627 ST-Soil carbon sequestration impacts. doi: 10.1126/science.1097396 [doi]

Le Roux B, Rouanet H (2010) Multiple correspondence analysis. Quantitative Applications in the Social Sciences (vol. 163). SAGE Publications, London

López Cordero J., González Cano J (2003) Conocer Mágina. CISMA, Carchalejo, Jaén

Marpsat M (2010) La méthode Alceste. Sociologie 1(1)

Parra-López C, Calatrava-Requena J (2005) Factors related to the adoption of organic farming in Spanish olive orchards. Spanish J Agric Res 3:5. doi: 10.5424/sjar/2005031-119

Parra-Lopez C, De-Haro-Giménez T, Calatrava-Requena J (2007) Diffusion and Adoption of Organic Farming in the Southern Spanish Olive Groves. J Sustain Agric 30:105-151. doi: 10.1300/J064v30n01_09

Patton QM (1990) Qualitative Evaluation and Research Methods, Second. Sage Publications Inc, London

Ploeg JD van der (2009) The New Peasantries: Struggles for Autonomy and Sustainability in an Era of Empire and Globalization. Earthscan, London.

Ponti L, Gutierrez AP, Ruti PM, Dell'Aquila A (2014) Fine-scale ecological and economic assessment of climate change on olive in the Mediterranean Basin reveals winners and losers. Proc Natl Acad Sci U S A 111:5598-603. doi: 10.1073/pnas.1314437111

Poppe KJ, Termeer CJ a. M, Slingerland M (2009) Transitions towards sustainable agriculture and food chains in periurban areas. Wageningen Academic Publishers, Wageningen, Netherlands.

Ratinaud P, Déjean S (2009) IRaMuTeQ: implémentation de la méthode ALCESTE d'analyse de texte dans un logiciel libre. MASH: Modélisation Appliquée aux Sciences Humaines et Sociales, Toulouse - Le Mirail

Reinert M (1983) Une méthode de classification descendante hiérarchique : application à l'analyse lexicale par contexte. Cah Anal Donnees 8:187-198.

Reinert M (1986) Un logiciel d'analyse lexicale: Alceste. Cah Anal Donnees 11:471-484.

Rodríguez-Entrena M, Arriaza M (2013) Adoption of conservation agriculture in olive groves: Evidences from southern Spain. Land use policy 34:294-300. doi: 10.1016/j.landusepol.2013.04.002

Rodríguez-Entrena M, Arriaza M, Gómez-Limón JA (2013) Determining Economic and Social Factors in the Adoption of Cover Crops Under Mower Control in Olive Groves. Agroecol Sustain Food Syst 38:69-91. doi: $10.1080 / 21683565.2013 .819478$

Rogers E (2003) Diffusion of innovations. The Free Press, New York

Ronchail J, Cohen M, Alonso-Roldán M, et al (2014) Adaptability of Mediterranean Agricultural Systems to Climate Change: The Example of the Sierra Mágina Olive-Growing Region (Andalusia, Spain). Part II: The Future. Weather Clim Soc 6:451-467. doi: 10.1175/WCAS-D-12-00045.1

Sánchez Martínez J., Gallego Simón VJ (2010) La olivicultura ecológica en Sierra Mágina: una aproximación inicial. In: ADR Sierra Magina. In: ADR Sierra Magina (ed) El olivar: Paisaje, patrimonio y desarrollo sostenible. Gráficas La Paz, Torredonjimeno, Jaén, pp 141-162

Sanz Cañada J, Garcia Bernes MD, Barneo Alcántara M (2013) El aceite de oliva de montaña en Jaén : cadena de valor y bienes públicos. The Institute for Prospective Technological Studies. Sevilla

Smit B, Skinner MW (2002) Adaptation options in agriculture to climate change: A typology. Mitig Adapt Strateg Glob Chang 7:85-114. doi: 10.1023/A:1015862228270 
Smith P, Martino D, Cai Z, et al (2008) Greenhouse gas mitigation in agriculture. Philisophical Trans R Soc B 363:789813. doi: $10.1098 / \mathrm{rstb} .2007 .2184$

TGSS (2007) Tesorería General de la Seguridad Social. http://www.seg-social.es/Internet_1/Estadistica/index.htm.

Umeå University (2013) OpenCode 4.0.

Vilar Hernández J, Velasco Gámez M. (2010) Incidencia del modo de explotación del olivo sobre la renta neta del productor. Retos y alternativas para el olivar tradicional extensivo. In: ADR Sierra Magina (ed) El olivar: Paisaje, patrimonio y desarrollo sostenible. Gráficas La Paz, Torredonjimeno, Jaén, pp 233-264

Warlop F (2006) Limitation des populations de ravageurs de l'olivier par le recours à la lutte biologique par conservation. Cah Agric 15:449-455. 